\title{
On the record
}

\section{John Launer}

Doctors are prolific writers, often without realising it. We each spend a great deal of time writing in patient files or on computer records. During a medical career, every one of us probably writes the equivalent of many full length novels or even an encyclopaedia. We write automatically, often at great speed, drawing mainly on a repertoire of verbal formulas that we have learned from others. Yet our notes reveal more than we are aware of-not just about our patients but about ourselves and the wider culture in which we live. Medical notes written a century ago, carefully entered with pen and ink into leather-bound ward ledgers, are vastly different from the notes in modern case folders, bulging with computer printouts and copies of correspondence. The differences are testimony not only to changing technologies and scientific knowledge. They show radically altered forms of thinking and social relations as well.

\section{PATIENT FILES}

A number of scholars in the last few years have looked closely at medical notes, examining how we listen selectively to patients' stories and transmute these into oral and written texts, often radically altering their meaning as we do so. One of the most impressive of these scholars is Petter Aaslestad, a professor of literature at Trondheim in Norway. During the 1990s he decided to apply his expertise as a literary critic to patient files. He took as his material a sample of a hundred sets of notes from 1890 onwards at Gaustad Hospital, the leading psychiatric hospital in Norway. His analysis was published in 1997 and soon become recognised in Scandinavia as a masterpiece of qualitative research. The book is now available in English, with the title The patient as text. ${ }^{1}$ It is especially fascinating for anyone with an interest in narrative studies or the history of psychiatry. However, its originality and depth of thought make it relevant for anyone who ever writes notes about patients. Almost certainly, you will recognise habits of your own in what he describes, and perhaps be as chastened by this as I was.

Correspondence to Dr John Launer, London Deanery, Stewart House, London WC1B 5DN, UK;

jlauner@londondeanery.ac.uk

\section{DISTANCING TECHNIQUES}

Aaslestad points out, for example, how doctors virtually never report patients' histories in their own uninterrupted words, or in direct quotations using the word 'I'. Instead, they diminish patients through a variety of distancing techniques, including a kind of telegrammatic writing that uses indirect speech and omits pronouns (eg, "feels unwell" instead of "Mr N said, 'I feel unwell" "). Similarly, although doctors always elicit case histories by systematic questioning, they rarely record the questions themselves. As a result, the notes generally create a false impression of giving a spontaneous patient narrative while actually following a logic dictated by the doctor.

Aaslestad also shows how doctors routinely characterise their patients by static and simplistic judgements ('calm and agreeable', 'utterly confused', 'extremely rude and challenging') rather than precise descriptions. He analyses how issues of gender, social class and power are embedded in the language of medical notes. Thus, women are 'unhappy in love' while a man has 'an affair that went awry'. Similarly, lower class patients are 'prone to drink', wealthier ones never so. If a patient has an influential relative like an MP, this is dutifully recorded.

\section{CULTURAL OBSERVATIONS}

These textual details are only the starting point for some wider cultural observations. Aaslestad illustrates how medical notes sometimes echo the literary genres of their era, including the modernist novel and the detective story. Inevitably, they also reflect the beliefs and ideologies of their time. In one era, religious belief is taken as a sign of virtue, whereas at a later time it is seen as cranky and suspect. The jargon of fashionable psychological theories, often in debased forms, seeps into and out of the texts, as doctors offer different and sometimes outrageous formulations of why patients behave as they do.

Many entries in the notes seem composed mainly in order to justify the diagnosis or management. If the diagnosis or management then changes, the flow of the text is adjusted accordingly, so that the shifting medical narrative always provides the grounds for whatever the doctors are thinking or doing. In more recent years, individual entries seem to be addressed to an increasing variety of imagined readers including other doctors, the hospital authorities, or inspectorates. In a strikingand depressingly familiar-extract from modern times, the notes of one patient propose an extended stay at the time of his admission, but support his discharge shortly afterwards when there is a lack of space on the ward.

While there is some historical evolution of ideas and rhetorical positions over the course of the century examined by Aaslestad, certain features remain constant. One of these is the doctors' expressions of irritation when patients do not follow their treatment. Another is their incomprehension when patients take a different view of the world from their own. However, Aaslestad is also careful to explain the professional and cultural contexts that have influenced the entries in the notes. He makes a distinction between good and bad writers, and points out how 'a writer's warmth, ignorance, lack of manners, empathy, self-righteousness, humour or self-criticism, all leave traces, almost independently of the record's medical content.'

\section{TELLING EXAMPLE}

Perhaps the most telling example in the book is one from recent years. Here, a doctor describes a patient who has asked to see his own file, following a change in the law on freedom of information:

'He has seen it, and as he read it through he smiled several times and said "I shan't comment on what it says, but I understand why you see it this way". It was impossible to get him to be specific about what he was reacting to'.

This patient's dignified silence, and his sense of the impossibility of getting professionals to understand his perspective in the way he understands theirs, speaks volumes. The extract offers support to a number of writers who argue that patients shouldn't only have the right to read their own notes-something that few of them seem to have done, and with little effect-they should be able to write in them too. ${ }^{2}$

Aaslestad argues convincingly that doctors need to become more aware of the political and cultural influences that govern their descriptions of patients, and to understand how oppressive these descriptions can become. In the words of one reviewer: 'This is a book for those of us who write patient files. Read it and consider how you describe your fellow beings'. 
Competing interests None.

Provenance and peer review Commissioned; not externally peer reviewed.

Postgrad Med J 2010;86:447-448.

doi:10.1136/pgmj.2010.101576

\section{REFERENCES}

1. Aaslestad P. The patient as text: the role of the narrator in psychiatric notes, 1890-1990. 0xford, Radcliffe Publishing, 2009.
2. Macnaughton RJ, Evans HM. Medical humanities and medical informatics: an uneasy alliance? Is there a role for patients' voices in the modern care record? Med Humanities 2004;30:57-8.

\section{BMJ Careers Fairs}

London: 1-2 October 2010

Birmingham: 8-9 October 2010

Register today at careersfair.bmj.com

The BMJ Careers Fairs are the UK's largest medical recruitment events, offering large exhibitions and seminar programmes, and covering a range of career related topics. Around 2400 doctors attend each year, drawn by the chance to talk directly to employers and receive career related advice. Register today and take the opportunity to attend our seminar programme or to meet representatives from Royal Colleges, Deaneries, locum agencies, and overseas recruiters. 